\title{
MASS-BALANCE MEASUREMENTS: PROBLEMS AND TWO NEW METHODS OF DETERMINING VARIATIONS
}

\author{
By LOUIS REYNAUd, MiCHEL VALlon, and ANNE LETREguilly
}

(Laboratoire de Glaciologie et Géophysique de l'Environnement, Centre National de la

Recherche Scientifique, 38402 Saint-Martin-d'Hères Cedex, France)

\begin{abstract}
The optimum continuation of series of mass-balance measurements and their extension to unmonitored glaciers are important problems in contemporary glaciology. For this purpose, two new practical survey methods are proposed, based on the linear-balance variations model of Lliboutry (1974). The first method is a simplified application of the linear model that uses only a data set limited to selected fixed-measurement sites. It was developed to obtain the mass-balance variation in cases where data are too scarce to obtain the global mass balance or to apply the Lliboutry algorithm. This simplified linear model is used with the 8 years' of surveys on glacier d'Argentière. The second method uses the continuity equation to derive the mass balance of a glacier sector delimited by two cross-profiles where the surface velocities, surface altitudes, and depths are known. By using this continuity method, the entire mass-balance series is established for a sector of glacier de Gébroulaz (Vanoise area, France) from 1908 to 1950, as well as for two sectors of Unteraargletscher (Oberland, Switzerland) from 1924 to 1981.
\end{abstract}

RÉsuMÉ. Mesures du bilan de masse: problèmes et deux nouvelles méthodes pour déterminer les variations. De nos jours, les problèmes des mesures des bilans de masse se situent principalement, soit dans le développement des systèmes de mesures, soit plus simplement dans la survie des series de mesures en cours. Dans cette optique, nous proposons deux nouvelles méthodes d'analyse des mesures de bilans effectuées sur les glaciers. Elles sont basées sur le modèle linéaire de variation des bilans proposé par Lliboutry (1974). La première méthode est une application simplifiée du modèle linéaire de variation, qui n'utilise qu'un système de mesures limitées à quelques sites fixes du glacier. Elle a été développée pour obtenir la variation du bilan dans le cas où les données ne sont pas suffisamment nombreuses pour obtenir le bilan de masse global ou pour appliquer l'algorithme de Lliboutry. Ce modèle linéaire simplifié est

\section{INTRODUCTION}

As the mass balance of a glacier is indicative of climatic input to the glacier system, it should be carefully monitored by glaciologists. Unfortunately, direct measurements were begun only recently: in 1946 for Storglaciarren and in 1948 for glacier de Sarennes. Practical methods have been used as an alternative to the direct glaciological method, allowing extension, by cartographical or hydrological means, of mass-balance studies over a longer span of time (Paterson, 1981). The I.H.D. saw an increase in glacier surveying and consequently a survey network is now available.

However, now that this enthusiastic I.H.D. period has ended, the continuation of these annual surveys, with the large amount of work necessary, has become a heavy burden. Not only must the series in progress be continued but also more characteristic points are required to complete our data to improve time consistency and area representivity. appliqué au glacier d'Argentière pour 8 années de mesures. La seconde méthode, basée sur l'équation de continuité, permet d'obtenir le bilan de masse d'un secteur de glacier limité par deux profils transversaux de sections droites connues, où ont été mesurées les altitudes et vitesses moyennes en surface. On a de cette façon établi la série entière des bilans pour le glacier de Gébroulaz (Massif de la Vanoise, France) de 1908 à 1950, ainsi que ceux de 2 secteurs du Unteraargletscher (Massif de l'Oberland, Suisse) de 1924 à 1981 .

Zusammenfassung. Massenbilanzmessungen: Probleme und zwei neue Methoden zur Bestimmung von Schwankungen. Die beste Fortsetzung von Messreihen der Massenbilanz und ihre Ausdehnung auf nicht überwachte Gletscher sind wichtige Probleme in der Glaziologie der Gegenwart. Zu ihrer Lösung werden auf der Grundlage des Modells der linearen Bilanzschwankungen von Lliboutry (1974) zwei neue praktische Vermessungsmethoden vorgeschlagen. Die erste ist eine vereinfachte Anwendung des linearen Modells, die nur einen Datensatz, der auf ausgewählte Stellen mit festgelegten Messungen beschränkt ist, benutzt. Sie wurde zur Gewinnung von Schwankungen der Massenbilanz in solchen Fällen entwickelt, wo Daten zu spärlich sind, um die globale Massenbilanz zu ermitteln oder den LliboutryAlgorithmus anzuwenden. Dieses vereinfachte lineare Modell wird auf die achtjährigen Beobachtungen am Glacier d'Argentière angewandt. Die zweite Methode benutzt die Kontinuitätsgleichung zur Herleitung der Massenbilanz eines Gletscherabschnittes, der von zwei Querprofilen begrenzt ist, in denen die Oberflächengeschwindigkeit, die Höhe der Oberfläche und die Dicke bekannt sind. Mit dieser Kontinuitätsmethode wird die gesamte Reihe der Massenbilanzen für einen Abschnitt des Glacier de Gébroulaz (Gebiet von Vanoise, Frankreich) zwischen 1908 und 1950 bestimmt, ebenso für zwei Abschnitte des Unteraargletschers (Berner Oberland, Schweiz) zwischen 1924 und 1981.

Under these circumstances, we must adjust the methodology in the light of the results already obtained and extend analysis to seek possible rules for wider application, especially in the potential use of remote sensing or satellite imagery of glaciers.

One of the major points which emerges from the analysis of glacier balances, in order to determine their climatic significance (reconstruction of past balances using meteorological parameters), their spatio-temporal distribution, or their dynamic response (changes in surface area, length, and levels), is that we use only the component varying with time. The mean mass balance depends too closely on the morphological characteristics of each individual glacier to be used easily.

This is the reason why we are investigating new methods that allow a simpler computation of the balance variations without having to make all the determinations necessary for a global budget. The two methods presented in this paper have been derived by the application of the linear model of mass-balance variations given by Lliboutry 
(1974). The first method, "the simplified linear model", gives the balance fluctuations from a limited stake array. It is applied to glacier d'Argentière (Mont Blanc area, France) using data collected at five cross-profiles for the period 1975-83.

The second method, "the continuity method", uses historical topographical surveys of two cross-profiles of a glacier to calculate the mean balance of that sector by means of the continuity equation. It has been applied to glacier de Gébroulaz (Vanoise area, France) for the period 1908-50 and to Unteraargletscher (Oberland, Switzerland) for the period 1924-81.

\section{The linear-balance variations model}

Lliboutry (1974) proposed that the balance $b_{j t}$, measured in year $t$ at location $j$, may be separated into three terms:

$$
b_{j t}=\alpha_{j}+\beta_{t}+\epsilon_{j t}
$$

where $\alpha_{j}$ is a geographical term depending only on location $j, B_{t}$ is the balance variation with time $t$, independent of the location for a given glacier $\left(\Sigma \beta_{t}=0\right)$, and $\epsilon_{j t}$ is a centred random residual, which gives ${ }^{t}$ the difference between the model and the field truth.

This approach is supported by the physical behaviour of annual mass-balance distributions of several glaciers, a property already suggested by various authors (Meier and Tangborn, 1965; Hoinkes, 1970). It appears that the balance varies by more or less the same amount along a glacier between two consecutive years. This is, in fact, a wellknown hydrological concept used by glaciologists since definition of the average net budget, which represents a linear distribution of the mass balance over the whole glacier. With the linear model, the balance computation no longer needs the always delicate and subjective distribution of the surface area since the variation of the balance is reached directly by a least-squares optimization of the network data. More details on this computation may be found in the complete statistical study by Lliboutry (1974). To assess its reliability, it would be necessary to compare it with another method, such as the volumetric method, which appears to be the most convenient reference. This has been done by Vallon and Leiva (1982) for 4 years of data, by direct measurements and by the photogrammetric method.

\section{Application of the linear model to the glacier d'Argentière data}

Glacier d'Argentière is one of the large valley glaciers on the north side of Mont Blanc. It has been surveyed since 1870 for length variations and since 1903 for levels and velocities at two cross-profiles on the lowest part of its tongue (Martin, 1978; Reynaud, 1978).

However, balance measurements were only begun recently, in 1975, with an extension of the other surveys to four cross-profiles on the upper part of the glacier (Fig. 1), at the request of E.D.F., the French electrical utility company, in order to follow the variations of the glacier and acquire a better knowledge of the water captured at the bed beneath the Lognan ice fall.

Although ten stakes are located on each cross-profile, only four or five give a comparable data set for the period 1976-83. Furthermore, cross-profiles 6 and 7 disappeared beneath the firn during the 1977 and 1978 period of heavy accumulation. Finally, only three cross-profiles are left to provide homogeneous data for the period 1976-83 (Table I).

The altitudinal mass-balance distribution shows an almost regular variation with an activity coefficient of $+0.70 \mathrm{~m}$ of ice for $100 \mathrm{~m}$ of altitude (Fig. 2). This graph also exhibits the mass-balance variation characteristic which is the basis of the linear-balance variation model: the annual variation of the balance is more or less of the same magnitude over the whole glacier.

To obtain this mean annual variation, $\beta_{t}$, we use the linear model in a simple way, which is in fact the first step of the complete computation suggested by Lliboutry (1974). This involves a comparison of the individual $b_{j t}$ with the mean value for the location $j$, giving $\beta_{j t}$. Then the final $B_{t}$ is the mean of the different values given by the three cross-profiles $(2,4$, and 5$)$.

This set of mass-balance variations can be compared with those obtained at the same time on glacier de SaintSorlin, $100 \mathrm{~km}$ to the south, in the Grandes Rousses area (Vallon and Leiva, 1982). The 8 years of measurements are

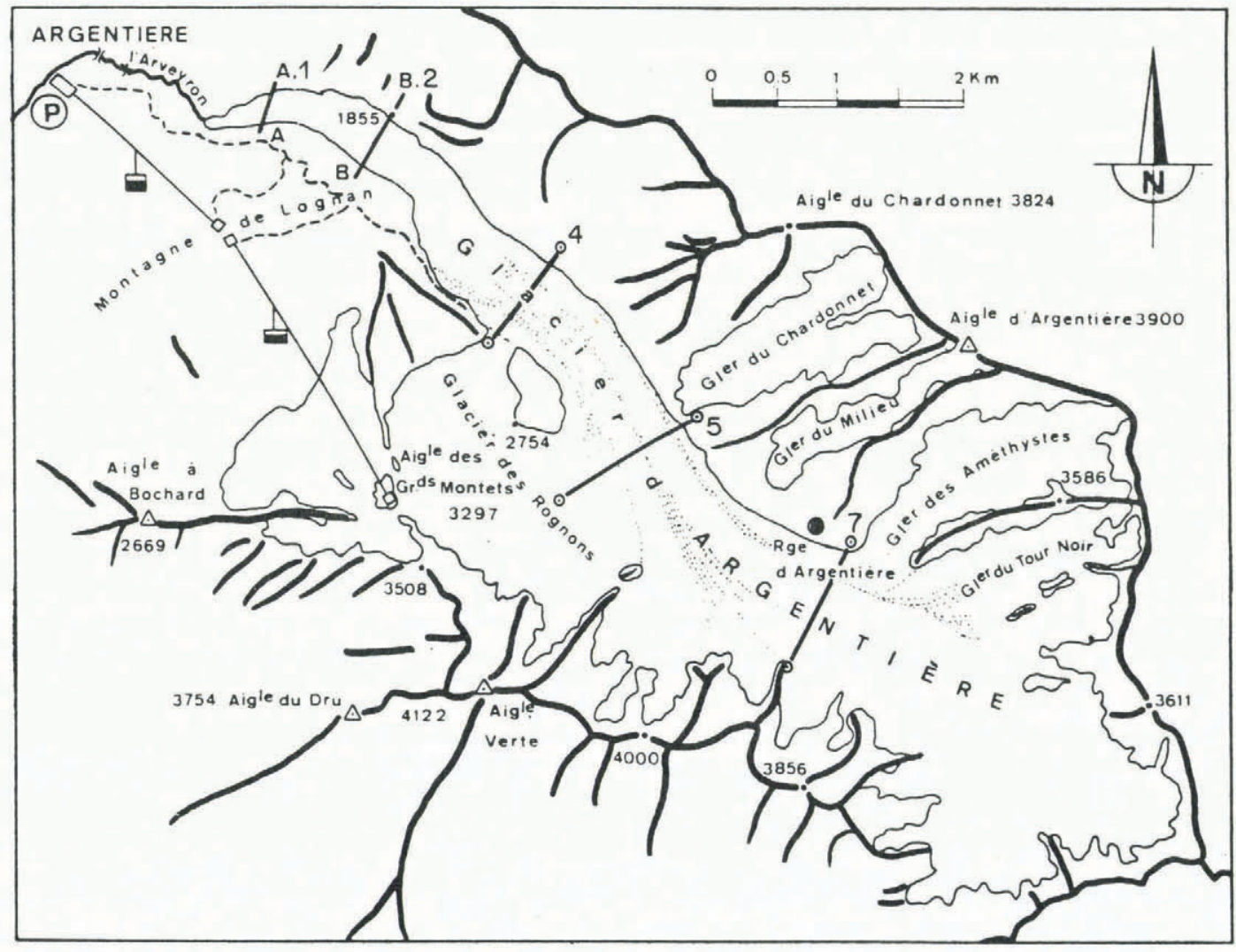

Fig. 1. Map of glacier d'Argentière showing locations of cross-sections. 
TABLE I. MASS-BALANCE DATA FOR GLACIER D'ARGENTIÈRE FOR 1976-83 IN METRES OF ICE. THE FIRST NUMBER IN EACH BOX IS THE SPECIFIC MASS BALANCE FOR THAT LOCATION. THE SECOND NUMBER IS THE DEVIATION FROM THE AVERAGE BALANCE AT THE SITE FOR THE WHOLE PERIOD

Year

$\begin{array}{cccccccc} & 7 & 6 & 5 & 4 & 2 & & \\ & (2740) & (2650) & (2560) & (2405) & (1850) & \beta_{t} & \Sigma \beta_{t} \\ 1976 & -2.75 & -3.64 & -3.83 & -5.11 & -9.05 & & \\ & & & -1.31 & -1.45 & -1.54 & -1.43 & -1.43 \\ 1977 & & -1.83 & -2.90 & -6.44 & & \\ & & & +0.69 & +0.76 & +1.07 & +0.84 & -0.59 \\ 1978 & & & -1.57 & -2.5 & -6.8 & & \\ & & & +0.95 & +1.16 & +0.71 & +0.94 & +0.35 \\ 1979 & & & -2.39 & -3.60 & -7.80 & & \\ & & & +0.13 & +0.06 & -0.29 & -0.03 & +0.32 \\ 1980 & -0.65 & -1.35 & -1.72 & -2.62 & -6.43 & & \\ & & & +0.80 & +1.04 & +1.08 & +0.97 & +1.29 \\ 1981 & -0.9 & -2.07 & -2.43 & -4.21 & -7.84 & & \\ & & & +0.09 & -0.55 & -0.33 & -0.26 & +1.03 \\ 1982 & -1.36 & -3.24 & -3.10 & -4.22 & -6.5 & & \\ & & & -0.58 & -0.56 & +1.01 & -0.04 & +0.98 \\ 1983 & -1.37 & -2.33 & -3.28 & -4.15 & -9.20 & & \\ & & & -0.76 & -0.49 & -1.69 & -0.98 & 0 \\ \alpha_{j} & (-1.41) & (-2.53) & -2.52 & -3.66 & -7.51 & & \end{array}$

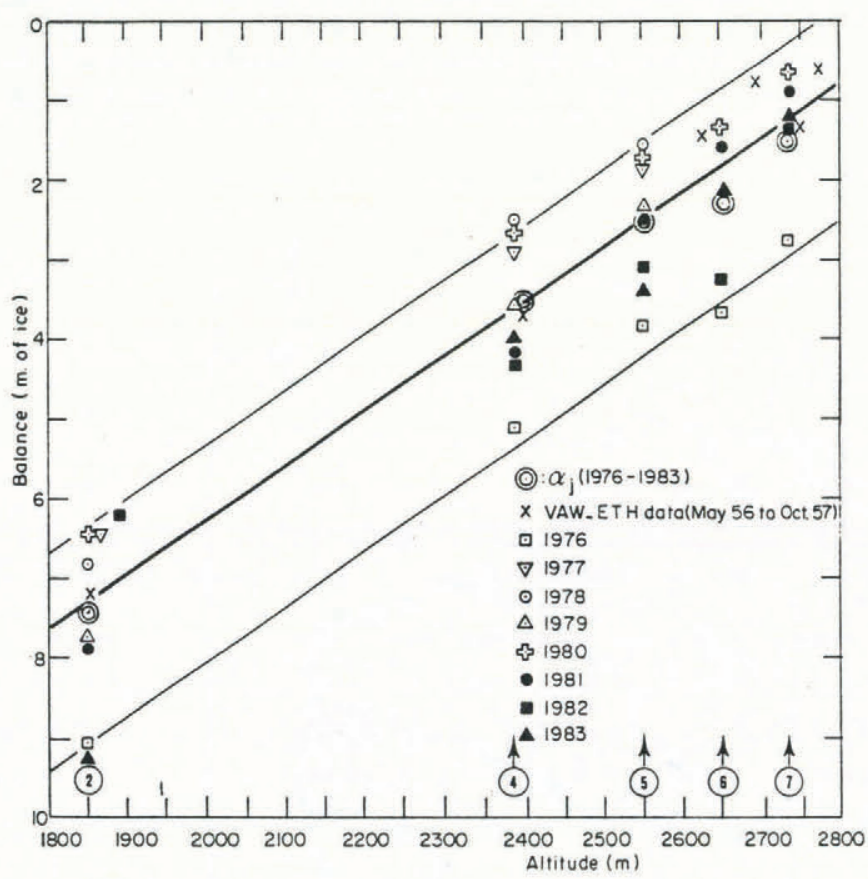

Fig. 2. Distribution of the average annual balance over glacier d'Argentière at different cross-sections versus the altitude for the period 1976-83.

very close to the first line, with a correlation coefficient of 0.93 (Fig. 3) (Letreguilly, unpublished).

To examine the influence of the differences between the series on the standard variations of the ice mass, the accumulated values are plotted in Figure 4, together with those given by Aletschgletscher (Aellen and Kasser, 1984). The curves obtained show a very similar time variation,

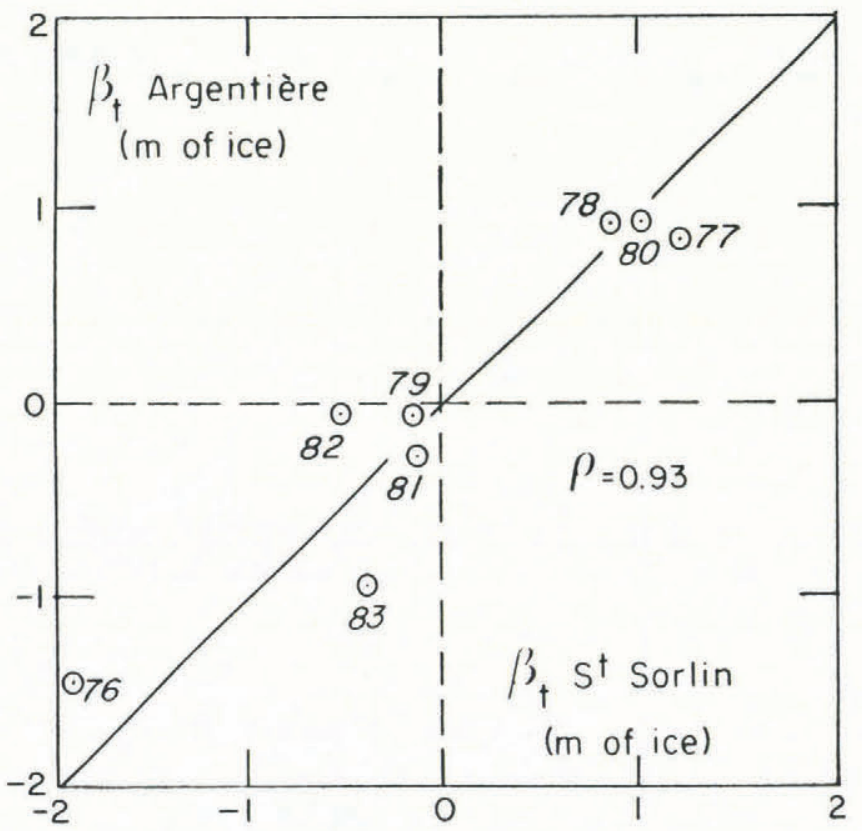

Fig. 3. Comparison of the balance variations $\beta_{\text {f }}$ given by glacier d'Argentière and glacier de Saint Sorlin for the period 1976-83.

covering practically the same magnitude range, in spite of the different methods used: the linear model for glacier de Saint-Sorlin and the hydrological method for Aletschgletscher.

In order to analyse globally the statistical significance of this data set, in view of its use with the linear model, one can compare the variance of the different terms. For each site we obtained a $\beta_{\text {it }}$ each year which is $\epsilon_{i f}$ from the mean $\beta_{t}$. The standard deviation of $\beta_{j t}$ is $0.93 \mathrm{~m}$ of 


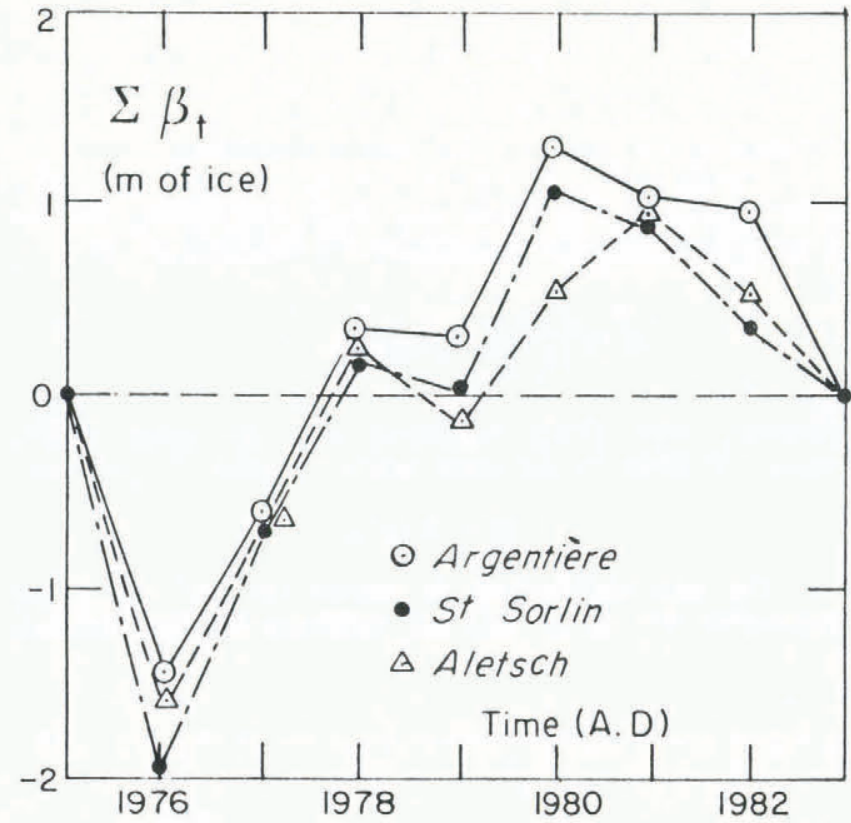

Fig. 4. Accumulated variations of $\boldsymbol{\beta}_{t}$ with time for glacier d'Argentière, glacier de Sarennes, and Aletschgletscher for the period 1976-83.

ice and that of the deviation $\epsilon_{j t}$ is $0.36 \mathrm{~m}$ of ice. The amount of the total variance accounted for by the linear model, $\tau$, is given by the quotient of the $\beta_{t}$ variance by the total variance of the sample

$$
\tau=\frac{3 \times \sum_{1}^{8} B_{t}^{2}}{\sum_{t=1}^{8} \sum_{j=1}^{3} B_{t j}^{2}}=0.85,
$$

while the residual variance

$$
\sum_{t=1}^{8} \sum_{j=1}^{3} \epsilon_{j t}^{2}
$$

contains the remaining $15 \%$ of the total variance not taken into account by the linear model.

Although this field-data analysis does not give the mass balance of the whole glacier, it does allow us to estimate the fluctuations of the mass balance in a very simple way, with a data sample limited to a few locations on the glacier, where variations of both level and velocity have been surveyed.

Such a method seems well suited to the monitoring of balance fluctuations, in order to include new glaciers in the survey system or simply to continue surveys already begun, especially under present circumstances where the amount of work has to be reduced.

It would clearly be of value to test the application of this linear model with the results of other usual methods applied to the same glacier. This could be done on some large glaciers presently surveyed by the hydrological method where both accumulation and ablation have been measured at several stakes. Even if such stake data are too scarce to define the mass balances, they might be sufficiently numerous to obtain their fluctuations. From this kind of comparison, the efficiency of the new method can be evaluated in order to determine the degree to which survey work can reasonably be reduced.

\section{MASS BALANCE BASED ON THE CONTINUITY EQUATION}

Monitoring the state of health of glaciers has always been a point of interest to glaciologists. In the beginning, variations in glacier length were thought to be most indicative of glacier health. Later, around the end of the last century, when boring techniques were less welldeveloped, topography was largely applied to the monitoring of glaciers. Glaciers were surveyed at different crossprofiles and painted rocks were placed to measure movement. In France, Vallot (1900) adopted this method and modified it in 1887, when he became aware that to assess annual variations in velocity on Mer de Glace, the painted rocks had to be replaced each year along the same profile. This method was applied on glacier de Gébroulaz by the

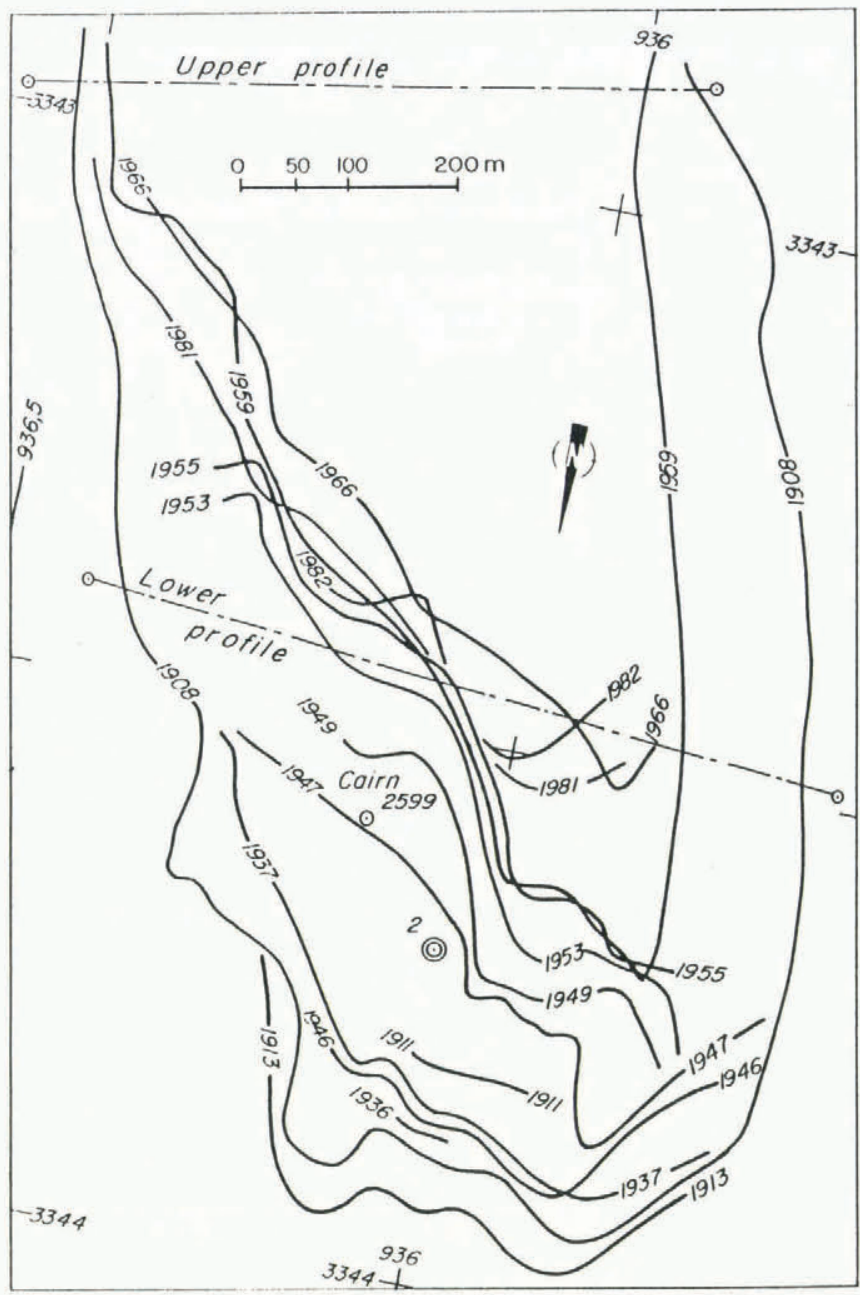

Fig. 5. Map of the tongue of glacier de Gébroulaz showing different terminal positions and locations of two cross-profiles.

French Water and Forest Resources Bureau (Eaux et Forêts) from 1907 to 1966 (Fig. 5) (Reynaud and others, 1983).

Annual mean altitudes of cross-sections together with mean velocities are given by 10 to 15 painted rocks (Figs 6 and 7). Since the topography is known (Fourno, 1974), the mass balance of the section between the two cross-profiles may be obtained by the continuity equation applied in a discrete manner to this sector (Fig. 8).

$$
q_{2}-q_{1}=A\left[\langle b\rangle-\left\langle\frac{\mathrm{d} h}{\mathrm{~d} t}\right\rangle\right]
$$

and

$$
\langle b\rangle=\frac{q_{2}-q_{1}}{A}+\left\langle\frac{\mathrm{d} h}{\mathrm{~d} t}\right\rangle .
$$




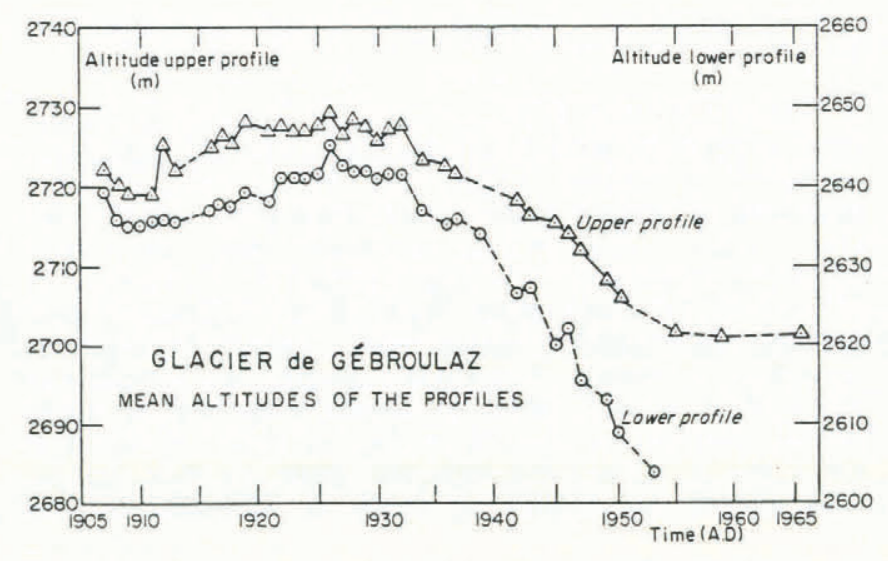

Fig. 6. Mean altitude variation of two cross-sections. where $q_{1}$ and $q_{2}$ are the annual ice fluxes through the two cross-sections, $A$ is the surface area of the glacier between the two profiles, $\langle b\rangle$ is the mean annual mass balance of this sector, and $\langle\mathrm{d} h / \mathrm{d} t\rangle$ is the mean annual altitude variation of the surface at the two cross-profiles.

Unfortunately, the velocity distribution over the whole cross-section of the surface area $S_{i}$ is not known, and yet it is required in order to compute the discharge of ice

$$
q_{\mathrm{i}}=\int_{S_{\mathrm{i}}} U \mathrm{~d} s=S_{\mathrm{i}}\langle U\rangle_{\mathrm{i}} .
$$

However, Nye (1965) suggested that the mean section velocity is given by the mean surface velocity $\langle U\rangle_{S_{i}}$. Thus

$$
q_{\mathrm{i}}=s_{\mathrm{i}}\langle u\rangle_{\mathrm{i}} .
$$

The only test available at present for this very simple assumption lies in the data for Athabasca Glacier (Canada),

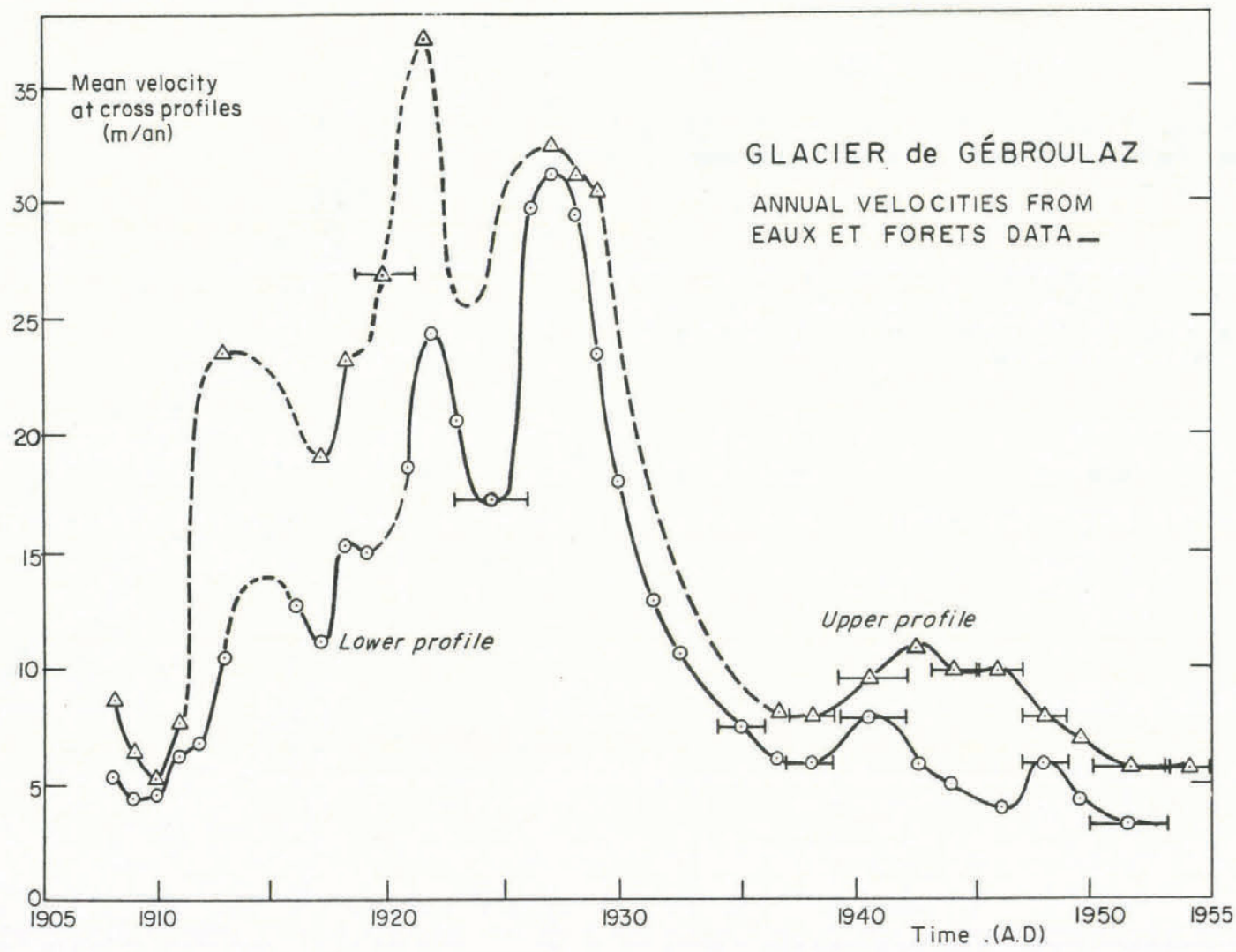

Fig. 7. Mean velocity variation at two cross-sections for 1907-55.

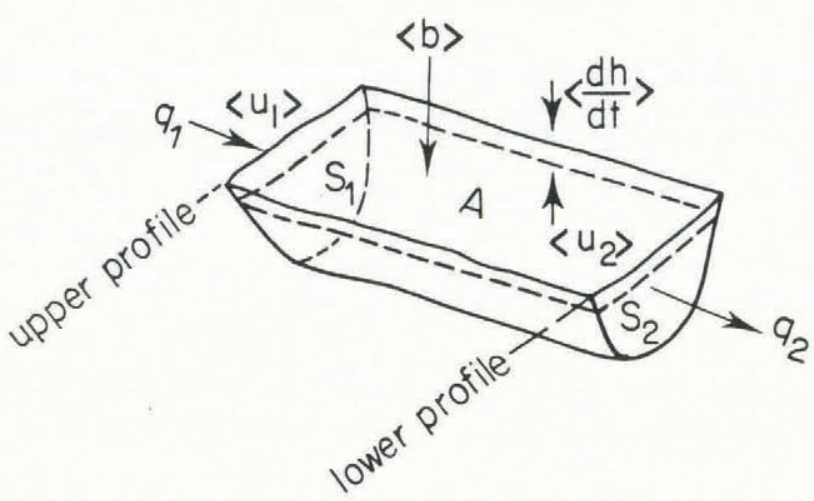

Fig. 8. Geometrical sketch of the continuity equation applied to part of a valley glacier between two cross-profiles. where Raymond (1971) actually measured the whole velocity distribution at three cross-sections. He found a mean surface velocity $12 \%$ higher than the mean cross-section velocity (Raymond, 1973). A simple translation gives

$$
q_{\mathrm{i}}=S_{\mathrm{i}}\langle u\rangle_{\mathrm{i}}=k S_{\mathrm{i}}\langle u\rangle_{S_{\mathrm{i}}}
$$

then

$$
\langle b\rangle=\frac{k}{A}\left(\langle u\rangle_{S_{2}} \cdot S_{2}-\langle u\rangle_{S_{1}} \cdot S_{1}\right)+\langle\mathrm{d} h / \mathrm{d} t\rangle .
$$

The general lack of data on this factor $k$, found to be around 0.9 for Athabasca Glacier, is a problem since it affects $\langle b\rangle$ directly. Therefore, the Nye assumption concerning flux computation presently remains an adequate approximation, especially in view of errors of at least similar magnitude in this kind of application within the areas of the cross-sections because they were determined by 
seismic soundings. For this reason, for want of a general rule, we will adopt the Nye assumption for flux computation.

Although the surface area between the two crosssections did not vary appreciably over the period 1908-50, remaining at about $30 \mathrm{ha}$, the mean altitude of the sector varied by approximately $100 \mathrm{~m}$. In order to maintain homogeneity of the mass-balance data, they are compared at the same altitude, that of 1950 , with a gradient of $0.6 \mathrm{~m}$ of water for each $100 \mathrm{~m}$ of altitude.

The complete data set necessary for the computations is given in Table II. They show a mean mass balance similar to that recently observed with ablation stakes: $\langle b\rangle=-1.90 \mathrm{~m}$ of ice, i.e. $-1.70 \mathrm{~m}$ of water equivalent. The deviation from the mean is given each year by

$$
B_{t}=\left\langle b_{t}\right\rangle-\langle\bar{b}\rangle \text {. }
$$

These data are plotted in Figure 9 together with the accumulated values in order to show the trends for the period. The expected sequences of balances favourable to

TABLE II. GLACIER DE GÉBROULAZ DATA FOR THE PERIOD 1907-50. SUBSCRIPTS 1 AND 2 INDICATE RESPECTIVELY THE UPPER AND LOWER PROFILES

\begin{tabular}{|c|c|c|c|c|c|c|c|c|c|c|c|}
\hline Year & $\begin{array}{c}Z_{1} \\
m\end{array}$ & $\begin{array}{c}V_{1} \\
\mathrm{~m} \mathrm{a}^{-1}\end{array}$ & $\begin{array}{l}S_{1} \\
\text { ha }\end{array}$ & $\begin{array}{r}Z_{2} \\
m\end{array}$ & $\begin{array}{c}V_{2} \\
\mathrm{~m} \mathrm{a}^{-1}\end{array}$ & $\begin{array}{l}S_{2} \\
\text { ha }\end{array}$ & $\begin{array}{l}A \\
\text { ha }\end{array}$ & $\begin{array}{l}\frac{d h}{d t} \\
\mathrm{~m} \mathrm{a}^{-1}\end{array}$ & $\begin{array}{r}C_{\mathrm{h}} \\
\mathrm{m}\end{array}$ & $\begin{array}{l}b_{t} \\
\mathrm{~m}\end{array}$ & $\begin{array}{l}\mathrm{B}_{t} \\
\mathrm{~m}\end{array}$ \\
\hline 1907 & 2723.0 & & & 2639.6 & & & & & & & \\
\hline 1908 & 2720.0 & 8 & 3.2 & 2635.9 & 5 & 1.5 & 33.0 & -3.35 & -0.16 & -3.65 & -1.94 \\
\hline 1909 & 2719.5 & 7 & 3.2 & 2635.0 & 4 & 1.5 & 32.9 & -0.70 & -0.16 & -1.22 & 0.49 \\
\hline 1910 & 2719.2 & 5 & 3.2 & 2635.3 & 4 & 1.5 & 32.9 & 0.00 & -0.16 & -0.41 & 1.30 \\
\hline 1911 & 2719.0 & 8 & 3.1 & 2635.5 & 6 & 1.5 & 32.9 & 0.00 & -0.16 & -0.58 & 1.13 \\
\hline 1912 & 2725.5 & 11 & 3.3 & 2635.7 & 7 & 1.5 & 33.1 & 1.60 & -0.17 & 0.59 & 2.29 \\
\hline 1913 & 2722.1 & 23 & 3.3 & 2635.4 & 11 & 1.5 & 33.1 & -0.10 & -0.17 & -1.87 & -0.16 \\
\hline 1914 & 2723.0 & 22 & 3.4 & 2635.9 & 13 & 1.5 & 33.2 & 0.70 & -0.18 & -1.00 & 0.71 \\
\hline 1915 & 2724.0 & 22 & 3.4 & 2636.4 & 13 & 1.6 & 33.4 & 0.75 & -0.18 & -0.98 & 0.73 \\
\hline 1916 & 2724.9 & 21 & 3.5 & 2636.9 & 12 & 1.6 & 33.5 & 0.70 & -0.19 & -1.00 & 0.71 \\
\hline 1917 & 2726.6 & 19 & 3.6 & 2637.5 & 11 & 1.6 & 33.7 & 1.15 & -0.20 & -0.49 & 1.22 \\
\hline 1918 & 2725.5 & 23 & 3.5 & 2638.5 & 15 & 1.7 & 33.8 & -0.05 & -0.20 & -1.71 & -0.01 \\
\hline 1919 & 2727.5 & 24 & 3.7 & 2639.4 & 15 & 1.7 & 34.0 & 1.45 & -0.21 & -0.51 & 1.19 \\
\hline 1920 & 2727.3 & 27 & 3.6 & 2639.0 & 15 & 1.7 & 34.0 & -0.30 & -0.21 & -2.38 & -0.67 \\
\hline 1921 & 2727.0 & 30 & 3.6 & 2638.5 & 18 & 1.7 & 33.9 & -0.40 & -0.20 & -2.62 & -0.92 \\
\hline 1922 & 2727.5 & 37 & 3.7 & 2641.6 & 24 & 1.9 & 34.3 & 1.80 & -0.22 & -0.95 & 0.76 \\
\hline 1923 & 2727.0 & 31 & 3.6 & 2642.5 & 21 & 1.9 & 34.4 & 0.20 & -0.22 & -1.91 & -0.20 \\
\hline 1924 & 2727.1 & 27 & 3.6 & 2641.0 & 17 & 1.8 & 34.2 & -0.70 & -0.21 & -2.58 & -0.88 \\
\hline 1925 & 2727.7 & 30 & 3.7 & 2641.6 & 18 & 1.9 & 34.3 & 0.60 & -0.22 & -1.66 & 0.05 \\
\hline 1926 & 2729.1 & 32 & 3.8 & 2645.0 & 30 & 2.1 & 34.9 & 2.40 & -0.24 & 0.44 & 2.15 \\
\hline 1927 & 2726.6 & 32 & 3.6 & 2643.6 & 36 & 2.0 & 34.6 & -1.95 & -0.22 & -3.11 & -1.40 \\
\hline 1928 & 2728.4 & 31 & 3.7 & 2642.9 & 29 & 1.9 & 34.6 & 0.55 & -0.23 & -1.24 & 0.46 \\
\hline 1929 & 2727.0 & 30 & 3.6 & 2642.8 & 23 & 1.9 & 34.5 & -0.75 & -0.22 & -2.55 & -0.85 \\
\hline 1930 & 2727.0 & 23 & 3.6 & 2643.0 & 18 & 1.9 & 34.5 & 0.10 & -0.22 & -1.37 & 0.33 \\
\hline 1931 & 2727.0 & 20 & 3.6 & 2641.5 & 13 & 1.9 & 34.3 & -0.75 & -0.21 & -2.14 & -0.43 \\
\hline 1932 & 2727.5 & 20 & 3.7 & 2641.5 & 13 & 1.9 & 34.3 & 0.25 & -0.22 & -1.25 & 0.45 \\
\hline 1933 & 2725.2 & 13 & 3.5 & 2639.5 & 10 & 1.7 & 33.9 & -2.15 & -0.20 & -2.86 & -1.16 \\
\hline 1934 & 2723.0 & 11 & 3.4 & 2637.5 & 8 & 1.6 & 33.5 & -2.10 & -0.18 & -2.70 & -1.00 \\
\hline 1935 & 2722.7 & 10 & 3.4 & 2636.2 & 8 & 1.6 & 33.3 & -0.80 & -0.18 & -1.45 & 0.26 \\
\hline 1936 & 2722.5 & 9 & 3.4 & 2635.0 & 7 & 1.5 & 33.1 & -0.70 & -0.17 & -1.32 & 0.39 \\
\hline 1937 & 2721.5 & 8 & 3.3 & 2635.5 & 6 & 1.5 & 33.1 & -0.25 & -0.17 & -0.84 & 0.86 \\
\hline 1938 & 2721.0 & 8 & 3.3 & 2634.8 & 6 & 1.5 & 32.9 & -0.60 & -0.16 & -1.16 & 0.55 \\
\hline 1939 & 2720.2 & 8 & 3.2 & 2634.0 & 7 & 1.5 & 32.8 & -0.80 & -0.16 & -1.29 & 0.42 \\
\hline 1940 & 2719.4 & 10 & 3.2 & 2631.1 & 8 & 1.3 & 32.3 & -1.85 & -0.14 & -2.39 & -0.68 \\
\hline 1941 & 2718.6 & 10 & 3.1 & 2629.3 & 8 & 1.2 & 32.0 & -1.30 & -0.13 & -1.89 & -0.19 \\
\hline 1942 & 2718.0 & 11 & 3.1 & 2626.5 & 6 & 1.1 & 31.6 & -1.70 & -0.12 & -2.42 & -0.71 \\
\hline 1943 & 2716.0 & 11 & 3.0 & 2627.0 & 6 & 1.1 & 31.5 & -0.75 & -0.11 & -1.52 & 0.19 \\
\hline 1944 & 2715.8 & 10 & 3.0 & 2623.5 & 5 & 0.9 & 31.0 & -1.85 & -0.10 & -2.48 & -0.77 \\
\hline 1945 & 2715.5 & 10 & 2.9 & 2620.0 & 5 & 0.8 & 30.5 & -1.90 & -0.08 & -2.54 & -0.83 \\
\hline 1946 & 2714.0 & 10 & 2.9 & 2622.0 & 4 & 0.9 & 30.7 & 0.25 & -0.08 & -0.59 & 1.12 \\
\hline 1947 & 2712.0 & 9 & 2.7 & 2615.5 & 5 & 0.6 & 29.6 & -4.25 & -0.05 & -4.53 & -2.83 \\
\hline 1948 & 2710.0 & 8 & 2.6 & 2614.2 & 6 & 0.5 & 29.3 & -1.65 & -0.04 & -2.07 & -0.36 \\
\hline 1949 & 2708.0 & 8 & 2.5 & 2613.0 & 6 & 0.5 & 29.0 & -1.60 & -0.02 & -2.00 & -0.29 \\
\hline 1950 & 2706.0 & 7 & 2.4 & 2609.0 & 4 & 0.3 & 28.3 & -3.00 & 0.00 & -3.20 & -1.49 \\
\hline
\end{tabular}

$Z$, mean cross-profile altitude; $V$, mean annual velocity; $S$, area of the sector; $\mathrm{d} h / \mathrm{d} t$, mean annual elevation change of the sector surface; $C_{\mathrm{h}}$, altitude correction as a function of the 1950 level with $\mathrm{d} b / \mathrm{d} z=0.006 ; b_{t}$, specific annual mass balance of the sector ( $\mathrm{m}$ of water); $\beta_{t}$, annual balance deviation from the mean for the period ( $m$ of water). 

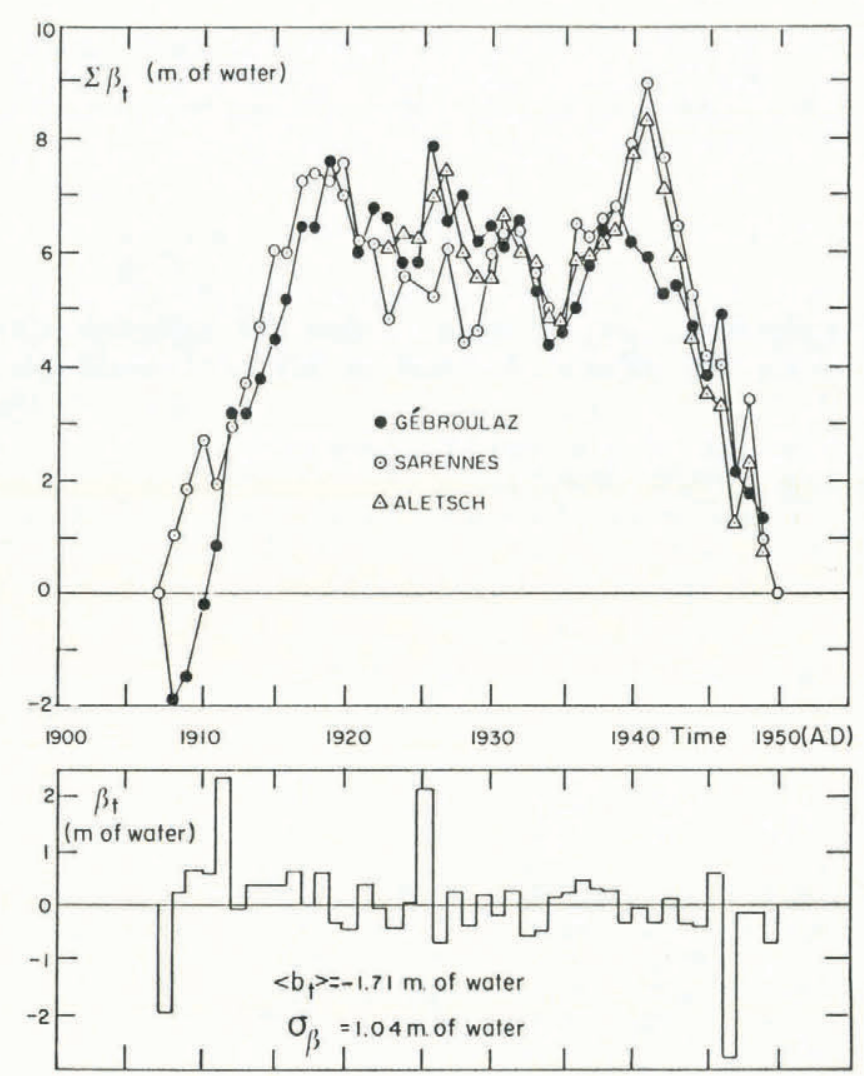

Fig. 9. B balance series from the continuity equation (1908-50) applied to glacier de Gébroulaz ( $m$ of water equivalent), and a comparison of cumulative variations with two long series available in the Alps for glacier de Sarennes and Aletschgletscher.

glacier growth (1908-18) are observed as well as those which are unfavourable (1940-50).

In the same way, the $\beta_{t}$ reconstructions for glacier de Sarennes (Martin, 1978; Valla, 1984) and the hydrological values for Aletschgletscher (Aellen and Kasser, 1984) are plotted. The usual patterns are mainly the same sequences of variation, giving a very similar maximum range. Nevertheless, note that field data or reconstructed values present more detailed variations with time while, on the contrary, the curve for glacier de Gébroulaz is smoother.

This is probably due to smoothing of the field data when some values are missing. We must, however, note that the information given by a whole sector is different from that obtained at individual stakes. A global balance includes the variations of melting in the central part of the glacier, generally clean and regular, where stakes are usually placed, as well as in the marginal areas, where there are more crevasses and debris covering. But the error sources are numerous; in addition to the Nye assumption, there are those errors related to velocities and surface areas. As opposed to altitudes which vary in a regular manner, velocities exhibit unexpected variations, so that missing measurements can hardly be replaced by interpolation. On the other hand, the lateral margins of the glacier were not surveyed regularly. Such surveys are imprecise in any case, since in many years the limits are hidden by morainic cover on the right margin or by firn on the left.

Nevertheless, these series are consistent. This further suggests that this new series of mass balances is representative, and that it constitutes a unique test of the reconstruction of the glacier de Sarennes balances of Martin (1978).

There are several glaciers which have been surveyed in the same way as glacier de Gébroulaz, with recent determination of the glacier-bed topography, that are prime candidates for further application of this new method.

Unteraargletscher in Switzerland provides this opportunity with a continuous set of data for the period
1924-81. The three cross-profiles: Misselenegg, Dollfus, and Brandlamm, give two computation sectors (Fig. 10). The basic data are presented in the annual reports of the Swiss Glacier Commission for the survey made by the K.W.O and in the papers of Jost (1953) and Haefeli (1970) for the topography of the bed. The data for Unteraargletscher are given in Table III.

The deviations from the mean balance derived from the continuity equation are plotted in Figure 11 , as well as their cumulated values to be compared with those for glacier de Sarennes and Aletschgletscher. The Unteraargletscher values are located within the range delimited by the two known series. The fluctuations are commonly very similar but occasionally, notably around 1970, they may be distinct. Nevertheless, one can find in these two sectors of Unteraargletscher all major features that marked the changes in mass balance, especially around 1940-50 and in the recent favourable period for glacier

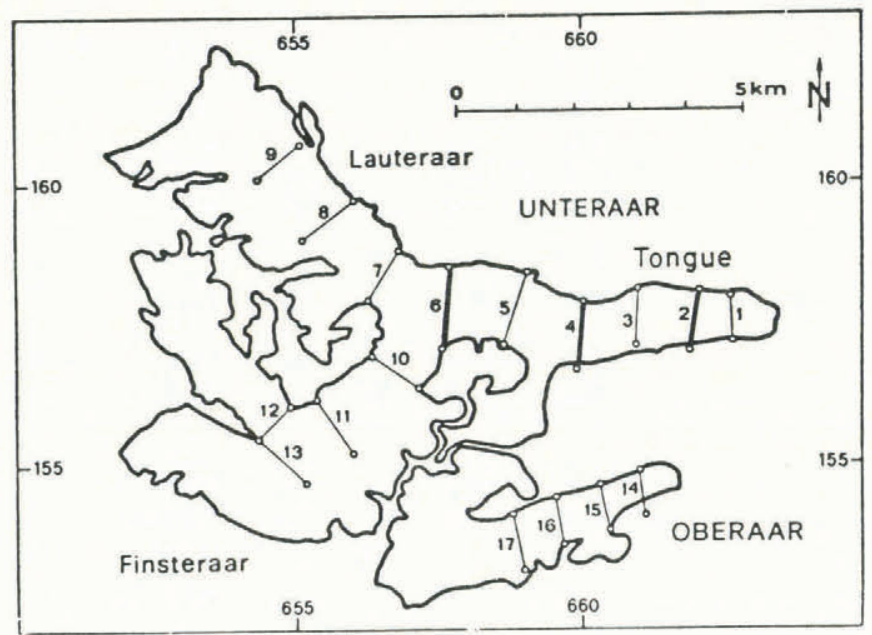

Fig. 10. Map of Unteraargletscher showing the location of cross-profiles (Aellen and Kasser, 1984). 6, Misselenegg; 4, Dollfus; 2, Brandlamm.
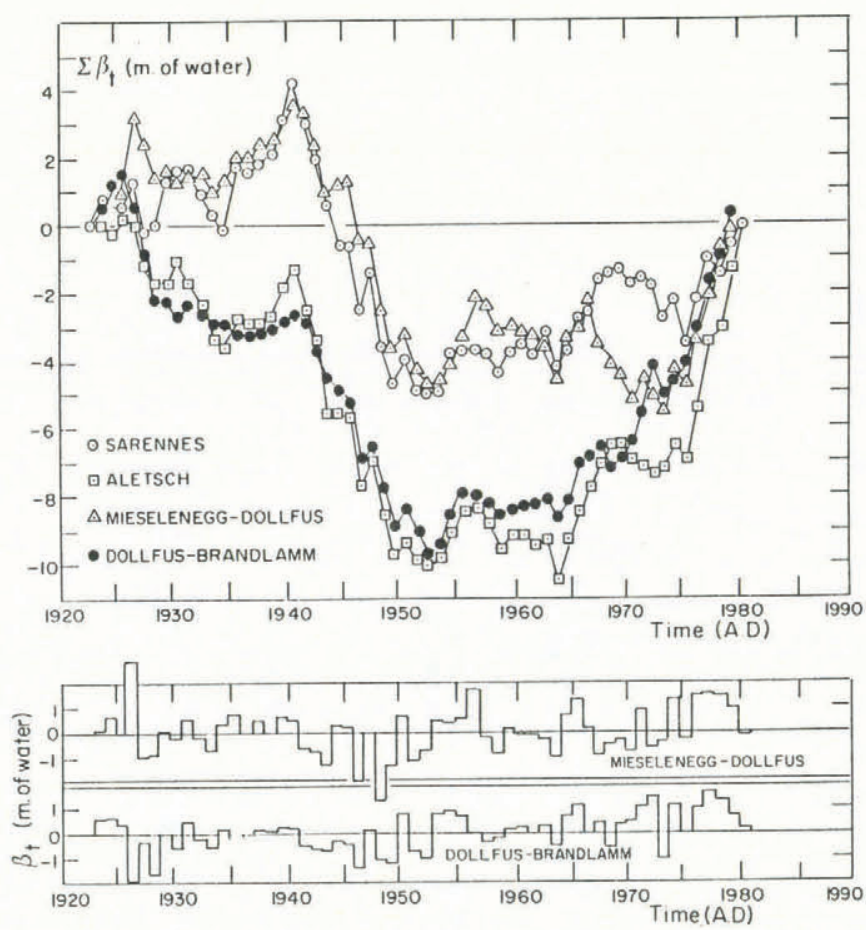

Fig. 11. Comparison of two mass-balance series derived from the continuity equation applied to two sectors of Unteraargletscher (Misselenegg-Dollfus and DollfusBrandlamm) with the series of Aletschgletscher and glacier de Sarennes for the period 1924-81. 
TABLE III. UNTERAARGLETSCHER DATA FOR THE PERIOD 1923-81. SUBSCRIPTS 1, 2, AND 3 INDICATE RESPECTIVELY THE MISSELENEGG, DOLLFUS, AND BRANDLAMM CROSS-PROFILES FOR ALTITUDE $(Z)$, VELOCITY $(V)$, AND CROSS-SECTION AREA $(S)$. $\mathrm{S}_{12}$ AND $\mathrm{A}_{23}$ ARE THE TWO SECTOR AREAS LIMITED BY DIFFERENT CROSS-PROFILES. THE CONTINUITY EQUATION APPLIED TO EACH SECTOR GIVES A SERIES OF SPECIFIC MASS BALANCES $\left(b t_{\mathrm{i}}\right)$ AND THE DEVIATIONS $\left(B t_{\mathrm{i}}\right)$ FROM THE MEAN

\begin{tabular}{|c|c|c|c|c|c|c|c|c|c|c|c|c|c|c|c|}
\hline Year & $\begin{array}{l}Z_{1} \\
\mathrm{~m}\end{array}$ & $\begin{array}{l}S_{1} \\
\text { ha }\end{array}$ & $\begin{array}{c}V_{1} \\
\mathrm{~m} \mathrm{a}^{-1}\end{array}$ & $\begin{array}{r}Z_{2} \\
\mathrm{~m}\end{array}$ & $\begin{array}{l}S_{2} \\
\text { ha }\end{array}$ & $\mathrm{m}^{V_{2}} \mathrm{a}^{-1}$ & $\begin{array}{r}Z_{3} \\
\mathrm{~m}\end{array}$ & $\begin{array}{l}S_{3} \\
\text { ha }\end{array}$ & $\mathrm{m} \mathrm{a}^{-1}$ & $\begin{array}{r}S_{12} \\
\text { ha }\end{array}$ & $\begin{array}{r}S_{23} \\
\text { ha }\end{array}$ & $b_{t 1}$ & $\beta_{t 1}$ & $b_{t 2}$ & $\beta_{t 2}$ \\
\hline 923 & 2420.9 & 38.8 & & 2287.5 & 25.9 & & 130.4 & 18.8 & & 276.4 & 217.4 & & & & \\
\hline 24 & 2420.7 & 38.7 & 40.0 & 2287.1 & 25.8 & 33.8 & 0.4 & 18.8 & 22.0 & 276.3 & 217.3 & -3.05 & 0.10 & -2.83 & 0.60 \\
\hline 1925 & 2419.8 & 38.6 & 37.8 & 2287.9 & 25.9 & 34.3 & 2129.5 & 18.7 & 21.7 & 276.3 & 217.2 & -2.48 & 0.67 & -2.79 & 0.63 \\
\hline 26 & 2418.4 & 38.4 & 36.8 & 2287.5 & 25.9 & 34.3 & 2129.4 & 18.7 & 20.2 & 276.1 & 217.1 & -3.10 & 0.05 & -3.08 & 0.35 \\
\hline 927 & 2421.9 & 38.9 & 40.0 & 2286.2 & 25.7 & 47.3 & 2127.7 & 18.5 & 24.0 & 276.3 & 216.5 & -0.69 & 2.46 & 29 & -1.87 \\
\hline 928 & 2420.2 & 38.7 & 38.8 & 2284.7 & 25.6 & 33.7 & 2127.3 & 18.5 & 18.0 & 275.8 & 216.1 & -4.09 & -0.94 & -3.78 & -0.35 \\
\hline 929 & 2418.9 & 38.5 & 37.2 & 2282.4 & 25.3 & 34.0 & 2125.0 & 18.3 & 17.5 & 275.2 & 213 & -4 & -0.89 & -5.04 & -1.61 \\
\hline 30 & 2417.4 & 38.3 & 36.4 & 2282.3 & 25.3 & 33.0 & 2124.0 & 18.2 & 16.2 & 275.0 & 214.0 & -3.09 & 0.06 & -3.46 & -0.03 \\
\hline 31 & 2416.3 & 8.2 & 37.5 & 2281.3 & 25.2 & 33.7 & 2122.7 & 18.0 & 17.1 & 274.7 & 214.3 & -3.39 & -0.24 & -3.99 & -0.56 \\
\hline & 2416.0 & 38.1 & 36.5 & 2281.0 & 25.2 & 32.9 & 2122.9 & 18.1 & 16.5 & 274.7 & 214 & -2.64 & 0.51 & -2 & 0.47 \\
\hline 33 & 2414.5 & 37.9 & 36.9 & 2280.2 & 25.1 & 34.1 & 2122.1 & 18.0 & 17.1 & 274.3 & 214.0 & -3. & -0.20 & 8 & -0.25 \\
\hline 934 & 2412.5 & 37.7 & 33.8 & 2278.3 & 24.9 & 31. & 2121.2 & 17.9 & 17.1 & 273.8 & 213. & -3.88 & -0.73 & -3.95 & -0.52 \\
\hline J & 2411.5 & 37.6 & 31.8 & 2277.5 & 24.8 & 29.9 & 2120.4 & 17.8 & 16.9 & 273.5 & 213.1 & -2.79 & 0.36 & -3.23 & 0.20 \\
\hline 1936 & 2411.5 & 37.6 & 33.2 & 2276.9 & 24.7 & 30. & 2118.6 & 17.7 & 15.9 & 273.4 & 212.5 & -2.37 & 0.78 & -3.74 & -0.31 \\
\hline 37 & 2410.5 & 37.4 & 31.0 & 2275.5 & 24.6 & 27.7 & 2117.6 & 17.6 & 15.2 & 273.0 & 212 & -3 . & 0.01 & -3 & -0.04 \\
\hline 政 & 2410.4 & 37.4 & 33.4 & 2274.6 & 24.5 & 29.4 & 2116.8 & 17.5 & 15.2 & 272.9 & 21 & -2 & 0.46 & -3.33 & 0.10 \\
\hline 1939 & 2409.2 & 37.3 & 31.9 & 2273.5 & 24.4 & 28.3 & 2115.9 & 17.4 & 15.0 & 272.5 & 211.2 & -3 & 0.00 & & 0.08 \\
\hline 194 & 2409.1 & 37.3 & 32.2 & 2272.7 & 24.3 & 29.0 & 2115.1 & 17.3 & 15.9 & 272.4 & 210.9 & -2 & 0.65 & 15 & 0.27 \\
\hline & 2409.0 & 37.3 & 34.0 & 2271.9 & 24.2 & 29. & 2114.3 & 17.3 & 15.2 & 272.2 & 210.5 & -2 . & 0.45 & -3.23 & 0.20 \\
\hline 194 & 2407.3 & 37.0 & 36.5 & 2270.6 & 24.1 & 31. & 211 & 17.1 & 15.2 & 271.8 & $20 s$ & -3 . & -0.62 & & -0.54 \\
\hline 943 & 2405.2 & 36.8 & 36.0 & 269.3 & 23.9 & 30 & 211 & 17.0 & 15.0 & 271.3 & 20 & -3. & -0.77 & -4 & -0.66 \\
\hline 844 & 2402.3 & 36.4 & 33.9 & 2267.2 & 23.7 & 29.5 & 4 & 16.8 & 14 & 70.6 & 20 & 1 & -1.27 & -4.13 & -0.71 \\
\hline 4 & 2402.0 & 36.4 & 33.5 & 2265.9 & 23.6 & 29.2 & 2107.9 & 16.7 & 14.1 & 270.3 & 207.9 & -2.88 & 0.27 & -3.77 & -0.34 \\
\hline 46 & 101.7 & 36.3 & 33.1 & 264.4 & 23.4 & 28. & 2106.2 & 16.6 & 13.6 & 270.1 & 20 & -2 & 0.16 & -3.89 & -0.46 \\
\hline 1947 & 2398.0 & 35.9 & 31.2 & 261.5 & 23.1 & 25.9 & 2103.2 & 16.3 & & 69.1 & & -5 & & & -1.43 \\
\hline ד & 2396.8 & 35.7 & 31.2 & 2260.4 & 23.0 & 25.3 & 2101.8 & 16.2 & 11.7 & 268.8 & 205 & -3 . & 0.01 & & 0.09 \\
\hline 194 & 2393.2 & 35.3 & 30.5 & 2257.2 & 22.7 & 24.5 & 2099.7 & 16.0 & 11.7 & 267.8 & 204.2 & -5 . & -1.98 & -4.54 & -1.11 \\
\hline 195 & 2390.6 & 35.0 & 29.7 & 2254.4 & 22.4 & 23.2 & 2096.6 & 15.7 & 11.0 & 267.0 & 203.0 & -4.48 & -1.33 & -4.63 & -1.20 \\
\hline & 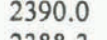 & 34.9 & 26.0 & 6 & 22.3 & 22. & .7 & 15.6 & 9.6 & 266.8 & 202 & -2 & 0.62 & -2 & 0.74 \\
\hline 195 & 2388.3 & 34.7 & 31.0 & 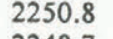 & 22.0 & 22 & 5 & 15.5 & 10.0 & 266.1 & 201 & -4 . & -1.12 & - & -0.76 \\
\hline 95 & 2385.8 & 34.4 & 27.3 & 2248.7 & 21.8 & 22 & 2 & 15.2 & 9. & 4 & & -3. & -0 & & -1.06 \\
\hline 1954 & 2385.2 & 34.3 & 29.1 & 2247.6 & 21.7 & 22.8 & 2089.5 & 15.1 & 8 & .1 & 20 & 2 & 0.43 & & 0.70 \\
\hline 1955 & 2384.2 & 34.2 & 27.4 & 2246.5 & 21.6 & 21.1 & 2089.0 & 15.1 & 8.7 & 264.8 & 199.6 & -2.80 & 0.35 & -2.58 & 0.84 \\
\hline 56 & 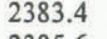 & 34.1 & .4 & 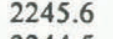 & 1.5 & 20 & & 15.0 & 7.9 & 264.6 & 195 & -2 . & 0.53 & -2 & 0.57 \\
\hline 957 & 2385.6 & 34.3 & 27.9 & 224 & 21.4 & 2 & & 14.0 & & & & & 1.67 & & -0.03 \\
\hline 1958 & 2384.5 & 34.2 & 25.8 & 2242.1 & 21.1 & 19.3 & .8 & 14.6 & 7.4 & 264.1 & 197 & -3. & -0.26 & & 0.38 \\
\hline 1959 & 2382.2 & 33.9 & 26.8 & 2239.7 & 20.9 & 19.2 & 2080.7 & 14.4 & 7.6 & 263.4 & 196.3 & -4 & -0.90 & -3.67 & -0.24 \\
\hline 60 & 2381.0 & 33.8 & 24.8 & 2238.1 & 20.7 & 18.1 & 2078.5 & 14.2 & 6.4 & 263.0 & 195.5 & -3.02 & 0.13 & -3.31 & 0.12 \\
\hline 6 & 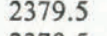 & 33.6 & .1 & & 20.6 & 19 & & 14 & 5. & .6 & 19 & -3.2 & -0.10 & & 0.19 \\
\hline 1962 & 2378.5 & 33.5 & 27.8 & 23 & 20.4 & 18 & .2 & 13. & 6. & 262.1 & 193 & -3.2 & -0.13 & -3.51 & -0.08 \\
\hline 1963 & 2377.0 & 33.3 & 2 & 3 & 20.2 & 18 & & 13 & 5 & .7 & 19 & 6 & -0 & - & 0.27 \\
\hline 1964 & 2374.6 & 33.0 & 27.4 & .230 .9 & 20.0 & 18. & 2069.4 & 13.5 & 5.1 & .0 & 19 & 5 & -1 & & -0.59 \\
\hline 6 & 2375.1 & 33.0 & 29.2 & 2229.6 & 19.9 & 18.8 & 2068.2 & 13.4 & 4.9 & 260.8 & 191.3 & -2.51 & 0.64 & -2.79 & 0.64 \\
\hline 96 & 75.6 & 33.1 & .2 & & 19.9 & 18 & & 13 & 4 & 9 & 19 & & 1.22 & & 1.06 \\
\hline 96 & 2374.3 & 32.9 & 28.3 & 228.7 & 19.8 & 18 & 8 & 13.0 & 4 & .5 & 19 & 1 & 0.13 & & 0.04 \\
\hline 196 & 2370.8 & 32.5 & 30.2 & 227.8 & 19.7 & 19. & .8 & 12.9 & 4. & 260.0 & 189 & 1 & -0.96 & -3 & 0.37 \\
\hline 196 & 2365 & 32.3 & 32. & & 19.6 & 19 & & 12.6 & 4 & 259.6 & 188 & -3 & -0.51 & 09 & -0.66 \\
\hline 197 & 2367.9 & 32.2 & 31.1 & 2225.2 & 19.4 & 18.4 & 2055.7 & 12.4 & 3.7 & 259.2 & 187.3 & -3.55 & -0.41 & -3.11 & 0.32 \\
\hline 197 & $236 \mathrm{C}$ & 32.0 & 34. & & 19. & 21 & & & 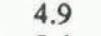 & & & -3 & -0.83 & & 0.39 \\
\hline & 2 & 31.9 & 34. & & 19.4 & 19. & & 12.1 & & 8 & 18 & & 3 & & 1.04 \\
\hline 19 & 2365.2 & 31.8 & 36.8 & 0 & 19.2 & 19. & 6 & 12.2 & 3. & 258.5 & 18 & -3 & -0.65 & & 1.38 \\
\hline 197 & 2364.6 & 31.8 & 31.9 & 222 & 19.0 & 20. & 2048.8 & 11.9 & 3. & 258.0 & 18 & -3 & -0.42 & -4 & -1.10 \\
\hline 197 & 2364.4 & 31.7 & 31.8 & 2221.4 & 19.1 & 20.4 & 2046.5 & 11.7 & 4.2 & 258.1 & 184.2 & -1.92 & 1.23 & -2.41 & 1.02 \\
\hline 197 & 2 & 3 & 29 & & 18.9 & 20 & & & 4. & & & -3 & -0.36 & & -0.00 \\
\hline 197 & & 31.6 & 26.3 & & 18.9 & 18. & & 11.5 & 3. & 25 & 18 & -17 & 1.38 & & 0.90 \\
\hline 197 & 2363.1 & 31.6 & 28.0 & 2219 & 18.9 & 17.4 & 1.0 & 11.3 & 4.4 & 2 & 18 & & 1.42 & & 1.52 \\
\hline 1979 & 2363.3 & 31.6 & 24.8 & 2219.2 & 18.9 & 15. & & 11 & 2.8 & 257.6 & 18 & -1 & 1.30 & -2.25 & 1.18 \\
\hline 198 & 2363.5 & 31.6 & 30.7 & 2218.6 & 18.8 & 19.5 & 2037.4 & 11.1 & 3.8 & 257.5 & 181.3 & -2 & 0.84 & -2.84 & 0.59 \\
\hline & 362.5 & 1.5 & 32.0 & 217.0 & 8.6 & 0.7 & 2035.2 & 10.9 & 3.6 & 257.1 & 180.4 & 3.35 & -0.20 & -3.44 & -0.01 \\
\hline
\end{tabular}


TABLE IV, STATISTICAL CHARACTERISTICS OF THE TWO MASS-BALANCE SERIES FOR UNTERAARGLETSCHER COMPARED WITH THOSE FOR ALETSCHGLETSCHER AND GLACIER DE SARENNES

$\begin{array}{lcc}\begin{array}{c}\text { Mass-balance series } \\ \text { m of water }\end{array} & \text { Mean } & \text { Standard deviation } \\ & & \\ \text { Mieselenegg-Dollfus } & -3.15 & 0.87 \\ \text { Dollfus-Brandlamm } & -3.43 & 0.74 \\ \text { Glacier de Sarennes } & -0.58 & 0.94 \\ \text { Aletschgletscher } & -0.16 & 0.89\end{array}$

growth. The characteristic values of the four series are given in Table IV. Despite their different numerical values, the standard deviations do not show statistically significant deviations over the 58 years, and the correlation coefficient for the two series for Unteraargletscher is about 0.53 .

However, we must note that the mean values of the balances for the two sectors are very close, giving an activity coefficient of only $0.2 \mathrm{~m}$ of water for each $100 \mathrm{~m}$ of altitude. Adopting this coefficient in the altitude correction for the lower sector, we obtain a new curve very similar (but not identical) to those for the upper sector and those for glacier de Sarennes (Letreguilly, unpublished). That is probably caused by the morainic debris covering the lower sector acting as an insulator and reducing the ablation as is usually observed on most glacier tongues of the same type.

Finally, a very decisive test for these series would be a comparison with some direct measurements of mass balance based on a set of ablation stakes. That would be a very good opportunity to assess the representivity of the longest series of direct mass-balance data in the Alpine region.

\section{CONCLUSION}

These two new methods may be regarded as adequate alternatives to the usual methods, either as an extension of measurements on new glaciers or simply as a continuation of ongoing surveys in the event of difficulties.

While the first method, the linear-variation method, using a stake array placed in the central and regular parts of glaciers gives some information on the balance variation similar to that obtained by the usual method, the second, the continuity method, takes account of the global balance of the sector in between the cross-sections, that is to say, with the influence of the debris cover and the crevasses near the edges. Furthermore, the large variations of the glacier tongues with time can present surfaces changing from very "clean" to totally debris-covered. This can cause non-homogeneous comparison series.

The second method also requires determination of the validity of the Nye assumption and the definition of several more general relationships on the flux computation for various cross-sectional shapes.

Nevertheless, this global method is more adapted to giving the actual balance variation and it is the only way to assess the representativeness of mass-balance reconstruction in the past by the use of historical survey data.

On the other hand, such cross-profile surveys are frequently abandoned, largely because of the amount of survey work. Nevertheless, the new possibility offered by distancemeters has reduced the work load by a factor of about two, making the topographical method increasingly attractive. A further advantage is that it also gives altitude and velocity variations with time. Information of this type is extremely useful, since it describes the metabolism of a glacier's variation with unexpected changes in velocities.

These methods should, nevertheless, be tested where data present such an opportunity or have been against different types of measurements on the same glacier.

\section{ACKNOWLEDGEMENTS}

This work was made possible by the extensive data available on glacier d'Argentière, glacier de Gébroulaz, and Unteraargletscher. We thank all those involved in providing these data, at E.D.F., CEMAGREF (Eaux et Forêts), and the Swiss Glaciers Commission. Field surveys on glacier d'Argentière were made under contract No. 9985112 with Electricité d'Emosson S.A. and on glacier de Gébroulaz under contract No. X-1985 with the Parc de la Vanoise. Finally, the two anonymous referees offered many interesting suggestions, most of which have been adopted.

\section{REFERENCES}

Aellen, M., and Kasser, P. 1984. Rapport préliminaire annuel de la Commission Suisse des Glaciers. Paris, Société Hydrotechnique de France. Section de Glaciologie.

Fourno, J.-P. 1974. Détermination de l'épaisseur du Glacier de Gébroulaz par prospection sismique. Travaux Scientifiques $d u$ Parc National de la Vanoise, 5, p. 9-40.

Haefeli, R. 1970. Changes in the behaviour of the Unteraargletscher in the last 125 years. Journal of Glaciology, Vol. 9, No. 56, p. 195-212.

Hoinkes, H. 1970. Methoden und Möglichkeiten von Massenhaushaltsstudien auf Gletschern. Zeitschrift für Glaziologie und Glazialgeologie, Bd. 6, Ht. 1-2, p. 37-90.

Jost, W. 1953. Das Grimselgebiet und die Gletscherkunde. Die Alpen, Jahrg. 29, Ht. 8, p. 203-14.

Letreguilly, A. Unpublished. Bilans de masse des glaciers alpins: méthodes de mesure et répartition spatiale-temporelle. [Third cycle thesis, Université de Grenoble, 1984.]

Lliboutry, L. 1974. Multivariate statistical analysis of glacier annual balances. Journal of Glaciology, Vol. 13, No. 69, p. 371-92.

Martin, S. 1978. Analyse et reconstitution de la série des bilans annuels du Glacier de Sarennes, sa relation avec les fluctuations du niveau de trois glaciers du Massif du Mont-Blanc (Bossons, Argentière, Mer de Glace). Zeitschrift für Glaziologie und Glazialgeologie, Bd. 13, Ht. 1/2, 1977, p. 127-53.

Meier, M.F., and Tangborn, W.V. 1965. Net budget and flow of South Cascade Glacier, Washington. Journal of Glaciology, Vol. 5, No. 41, p. 547-66.

Nye, J.F. 1965. The flow of a glacier in a channel of rectangular elliptic or parabolic cross-section. Journal of Glaciology, Vol. 5, No. 41, p. 661-90.

Paterson, W.S.B. 1981. The physics of glaciers. Second edition. Oxford, etc., Pergamon Press. (Pergamon International Library.)

Raymond, C.F. 1971. Flow in a transverse section of the Athabasca Glacier, Alberta, Canada. Journal of Glaciology, Vol. 10 , No. 58 , p. $55-84$

Reynaud, L. 1973. Flow of a valley glacier with a solid friction law. Journal of Glaciology, Vol. 12, No. 65, p. $251-58$.

Reynaud, L. 1978. Glacier fluctuations in the Mont Blanc area (French Alps). Zeitschrift für Glaziologie und Glazialgeologie, Bd. 13, Ht. 1/2, 1977, p. 155-66.

Reynaud, L., and others. 1983. Analyse et synthèse des mesures glaciologiques effectuées sur le Glacier de Gébroulaz, Massif de la Vanoise, France, by L. Reynaud, M. Vallon, and C. Carle. Travaux Scientifiques du Parc National de la Vanoise, 13, p. 9-23.

Valla, F. 1984. Bilans du Glacier de Sarennes. Houille Blanche, $6 / 7$, p. $526-27$.

Vallon, M., and Leiva, J.C. 1982. Bilan de masse et fluctuations récentes du Glacier de Saint-Sorlin (Alpes Françaises). Zeitschrift für Glaziologie und Glazialgeologie, Bd. 17, Ht. 2, 1981, p. 143-67.

Vallot, J. 1900. Annales de l'Observatoire Météorologique du Mont Blanc. Tomes 4, 6 et 7. Paris, Stenhail. 